\title{
A Study on the performance of Skill Development Centres in Haryana
}

\author{
${ }^{1}$ Dr. Karamvir Sheokand, ${ }^{2}$ Dr. Sonia, ${ }^{3}$ Dr. Garima Dalal, \\ ${ }^{123}$ Assistant Professor, IMSAR Maharshi Dayanand University
}

\begin{abstract}
Today all economies need skilled workers to meet international quality standards, increase their foreign trade, bring improved technology to their domestic industries and enhance their industrial and economic development. Skills development is used to describe a wide range of institutions and jobs that affect employment and income. The goal of the research is to analyse the performance of skill development centres and their role in creating job skills among trainees in Haryana. Frequency, Percentage, Cross tabulation, Chi square test etc. were used for the purpose of analysing the data. The findings indicate that the performance of skill centres play an effective role in creating and enhancing competency for job as well as job acquirement up to an extent.
\end{abstract}

Keywords: Skill development, Skill Centres, Economies, Trainees

\section{Introduction}

A growing number of countries have achieved the goal of universal primary education and some are approaching this goal and building a pipeline for young people waiting to further their education and training to improve their employment opportunities and higher incomes. When it comes to recruiting young and old for employment, subtle changes are taking place. The conversation shifts from talking about education to talking about skills. The term skills development is used to describe a wide range of institutions and jobs that affect employment and income. Access to secondary and tertiary education is as important as the provision of technical and vocational education.

Skills development is a very broad concept involving a large, diverse supplier community, and as a result, these developments are very difficult to monitor. Skills acquired in the later stages of the life cycle after graduating from formal education come from a variety of sources that are extremely difficult to trace and measure in terms of quantity and quality. The diversity of skills demanded by employers and the different resources they are produced make it very difficult to look at the diversity of skills. While academic exclusion is measured by formal school years, skills exclusion does not have the same meaning.

Today all economies need skilled workers to meet international quality standards, increase their foreign trade, bring improved technology to their domestic industries and enhance their industrial and economic development. Therefore, skills and knowledge become the key to the economic growth and development of any country. As it has been observed, high-skilled countries tend to have higher GDP and per capita income levels and adapt more effectively to the challenges and opportunities of the world of work. In India, skills development is also more important than the socioeconomic and demographic perspective

The World Bank conducts periodic Investment Climate Assessment (ICA) surveys to identify barriers to growth. More than 100 countries participated in one or more of these trials. Skills are one of the numbers of obstacles that can grow. Research asks questions about whether business trains and the characteristics of those who are trained. The ICA study shows strong regional differences in award winning training by nearly two-thirds of coaches in East Asia and less than one-fifth training in the Middle East and North Africa. In a country like China, about 90 percent of employers report training, while in India the figure drops to less than 20 percent.

The skills development environment in India is complex. The public sector dominates the vocational training centre in India. However, the participation of the private sector and the emergence of the skills development space have begun to grow, especially in the training sector. It is estimated that India will meet the demand for 500 million skilled workers by 2022. But India still faces difficulties in providing skilled workers as currently, only $2 \%$ of all workers in India have received skills training. According to the Government of India, 93\% of employees are in the informal sector, which are not supported by a formal skills development program. The information channels and the skills development process are unclear or vague. 


\section{DOI: $10.51386 / 25815946 /$ ijsms-v4i6p119}

\section{Measures of skill development in India:}

The Ministry of skill development and entrepreneurship is responsible for integrating all skill development initiatives across the country, eliminating the gap between the recruitment and supply of skilled workers, building a technical and technical training framework, skills development, building new skills, and innovation not only in existing jobs but also in construction. The Department aims to be able to measure at a faster rate and higher levels to achieve its vision of 'Skilled India' Assisted in its operational arms National Skill Development Agency (NSDA), National Skill Development Corporation (NSDC), National Skill Development Fund (NSDF) ) and 33 Sector Skill Councils (SSCs) and 187 NSDC trained partners. The Department also intends to work with an existing network of skills development institutions, universities and other cooperatives in this field. In addition, working with relevant Central Ministries, Government Governments, international organizations, industry and NGOs has initiated a multilevel involvement and vigorous implementation of skills development efforts.

The National Skill Development Corporation India (NSDC) has been established as one of its subsidiaries, a Public Private Partnership with a major skills development project in India. The NSDC is a unique model built on good thinking using a basic philosophy based on the pillars of creating and promoting the construction of large, state of scarce training facilities, reducing risk by donating patient money (Includes grants and equity) and Empowering construction and sustainability of support systems needed for skills development. This includes Industrial Sector Councils. They are able to develop Skills Management System (SDMS) with 606 training partners, 24092 training centres, 27047 trainers, 20 job sites, 29 testing agencies and 2808 competent examiners. The National Skill Development Agency (NSDA), an independent body (registered as an organization under the Association Registration Act of 1860) is mandated to consolidate and coordinate skills development activities in the country, as part of the Department of Skills and Entrepreneurship (MSDE) .

The National Skill Development Fund was established in 2009 by the Government of India to raise funds for both the Public Sector and the Government Skills Development Agency. The Fund is provided by various Government sources, as well as other donors / donors to develop, promote and develop skill in Indian youth through various sector programs. The NSDC serves as a promoter for skills development by funding businesses, companies and organizations that provide skills training. It also develops appropriate models to enhance, support and coordinate the efforts of private companies. As at 31 March 2015, the NSDF has issued Rs. 2333 pounds went to NSDC for skills development programs including National Skill Certification and Monetary Reward Scheme (STAR) and UDAAN Scheme (J\&K). Sector Skills Councils (SSCs) Sector Skills Councils have been established as independent industry led institutions by the NSDC. They create Occupational Standards and qualifications, develop skills frameworks, conduct Training Programs, conduct skills gap courses and assess and validate trainees in a curriculum that is aligned with the National Performance Standards they have developed

\section{HARYANA SKILL DEVELOPMENT POLICY}

Shri Anant Prakash Pandey Mission Director, Haryana Skill Development Mission said "Youth" is the value and pillar of all countries, which is why strengthening them, we at Haryana Skill Development, focus on their "Development and Development" skills and strive for Success through skills development initiatives and the Entrepreneurship program and programs in our province.

The Haryana Skill Development Mission (HSDM) was established in May 2015 by the State Government with the aim of empowering the youth to participate in the economic and social development of HARYANA and INDIA. The Mission is one way to communicate with Government to build and direct skills development programs across the Department. The HSDM serves as an integrated machine that integrates the efforts of the various departments of the State in achieving the goal of State skills development.

They already have $80+$ courses, which include $15+$ different categories available for Haryana youth in our programs such as SURYA, SAKSHAM, PMKVY etc. Comprised of a team of professionals and training partners at the end, each program is initiated with a vision to develop future knowledge, skills and get a job or become a successful entrepreneur.

Pradhan Mantri Kaushal Vikas Yojana (PMKVY) Pradhan Mantri Kaushal Vikas Yojana (PMKVY) is a highly skilled training program for the new Ministry of Skill Development \& Entrepreneurship (MSDE). The aim of the 


\section{DOI: $10.51386 / 25815946 /$ ijsms-v4i6p119}

competency and award-winning program is to empower and motivate more young Indian people to start skills training and become employable and earn a living.

\section{Present Status of Skills in India}

To help diversify, India will need to empower its workers with the right kind of skills.

This section therefore outlines the current skills levels of Indian workers aged 15-59 in the form of their general education and training levels.

- School dropout rates were estimated to be $50 \%$ in the 514 to $86 \%$ age group after 15 years and in contrast the level of staff participation increased rapidly after 14 years and resulted in uneducated staff receiving it is difficult to acquire high skills.

- $\quad 38 \%$ of Indian workers are educated, $25 \%$ have undergraduate or advanced education and the remaining $36 \%$ have a middle and high level of education.

- $\quad 80 \%$ of Indian workers do not have sales skills.

- Only $2 \%$ received formal vocational training and $8 \%$ illegal training, which means that very few new entrants have commercial skills compared to developed economies like Korea (96\%), Germany (75) \%, Japan (80\%) and the United Kingdom (68\%). In short, it can be said that although there has been significant progress in terms of learning, many instances of illiteracy are crippling Indian workers even today. The above facts are a stark reminder that India's dividend of the people may quickly turn into a people's dream if skills are not handed over to new and existing employees. Therefore, there is a need for increased capacity and capacity for skills development programs.

The Government of Haryana in its endeavour to promote employability and entrepreneurship of its youth has been creating and continues to establish world class skill infrastructure in the State. It is the State's endeavour to put Haryana as a Skill Capital of the country over the next five years. HSDM has set up a daily governance meeting to speed up the execution of deliverables. As per the data on 1/9/2021, 89904 candidates have been enrolled under various schemes. Out of these 79953 have been trained, 62270 assessed, 53478 certified and 14369 have been placed in Haryana. During Covid 19 pandemic, sixteen lakhs of facemasks have been distributed to the people in the state of Haryana. Recognition of Prior learning (RPL) is a key component of PMKVY 2.0. This scheme evaluate existing knowledge and also upskill them. One training partner has been empanelled under RPL. 2562 trainees has been certified and 748 have been placed. 30 trainees have been assessed and 28 certified under EDP (Entrepreneurship Development Programme). This programme is in association with CSC E- Governance Services. The Udyog Mitra model is an innovative scheme to develop skilled resources for the industry. The status of various training canters and placement is shown below:

\begin{tabular}{|c|c|c|c|c|c|c|}
\hline Department & $\begin{array}{l}\text { Training } \\
\text { Center }\end{array}$ & $\begin{array}{l}\text { Job } \\
\text { Role }\end{array}$ & $\begin{array}{l}\text { Enrolled } \\
\text { Candidates }\end{array}$ & $\begin{array}{l}\text { Trained } \\
\text { Candidates }\end{array}$ & $\begin{array}{l}\text { Certified } \\
\text { Candidates }\end{array}$ & $\begin{array}{l}\text { Placed } \\
\text { Candidates }\end{array}$ \\
\hline Total & 1421 & & 238223 & 189967 & 163010 & 59379 \\
\hline Horticulture Department & 3 & 11 & 120 & 105 & 105 & 0 \\
\hline Technical Education Department & 16 & 8 & 9643 & 6761 & 6761 & 1512 \\
\hline Tourism Department & 5 & 2 & 990 & 703 & 703 & 11 \\
\hline Urban Local Bodies Department & 73 & 64 & 18084 & 16434 & 13331 & 5428 \\
\hline HARTRON & 81 & 1 & 68932 & 38354 & 38354 & 2663 \\
\hline $\begin{array}{l}\text { Animal Husbandry \& Dairying } \\
\text { Department }\end{array}$ & 23 & 3 & 7555 & 7555 & 7555 & 7555 \\
\hline $\begin{array}{lll}\begin{array}{l}\text { Department } \\
\text { Development }\end{array} & \text { of } & \text { Rural } \\
\end{array}$ & 82 & 56 & 37416 & 35796 & 41596 & 27077 \\
\hline $\begin{array}{l}\text { Welfare of SCs and BCs } \\
\text { Department }\end{array}$ & 1 & 4 & 4609 & 3870 & 920 & 764 \\
\hline $\begin{array}{l}\text { Haryana Skill } \\
\text { Mission }\end{array}$ & 74 & 69 & 89904 & 79953 & 53478 & 14369 \\
\hline $\begin{array}{l}\text { Sainik and ArdhSainik Welfare } \\
\text { Department }\end{array}$ & 7 & 4 & 970 & 436 & 207 & 0 \\
\hline $\begin{array}{l}\text { Department of Secondary } \\
\text { Education }\end{array}$ & 1056 & 12 & 0 & 0 & 0 & 0 \\
\hline
\end{tabular}

Source: www.hsdm.org.in 


\section{DOI: $10.51386 / 25815946 /$ ijsms-v4i6p119}

\section{Review of Literature}

Agrawal, T. (2012) investigates India's vocational education and training (VET) system, as well as the issues and difficulties that it faces. This study uses a large-scale nationally representative household survey and did a comparative study between labour market outcomes of vocational graduates and with the general secondary graduates. The results indicate that vocational graduates (especially in the age category of 15-29 years) have a high unemployment rate as compared to secondary graduates.

Anjali Vyas (2018) conducted a study titled, "The Impact of Skill Development on Women Empowerment", revealed that women empowerment is one of the biggest tools for the 'effective development' of any country. It helps in preventing the women from economic and gender-based discrimination, also it helps in boosting their confidence. They need to be skilled to be able to better serve their families at home as well as in their profession. Skill development not only prepares them for jobs but also improves their quality of work.. The basic need for empowering women is to instil the required skills and abilities to shape up their overall personality and raise their status within society.

Anton Nivorozhkin (2005), the study discusses government-sponsored vocational training programmes and retraining to improve skills on the job. The study found that government-sponsored vocational training programmes don't need to be effective policy tools because the data does not allow the calculation of any general equilibrium effects. The propensity score matching method was used to understand whether participation in the training programmes helps in increasing monthly salaries. The study concludes that re-training programmes may take time; hence it may appear that those who were not trained obtained a job faster. The study recommends that training programmes are effective but they are short term.

Baker (2000), covers the design and implementation of assessment of different social programmes such as poverty-reduction, education, ALMP, among others. The major findings of the study are that the results of implementing various programmes are largely dependent on the institutional settings of the analyzed country, and monitoring of programmes, implementation coupled with new methods for the analysis of programmes outcome needs to be widely applied to make rigorous statements about the effect and effectiveness of social programmes.

Bhardwaj (2014) The study explores the role of training programmes in improving women entrepreneurship skills. The author uses various demographic, economic and perceptual variables to understand the impact of training programmes. Findings suggest that women need proper training and education as it helps to stimulate creative ideas and learn prerequisite skills for managing their business. The study also recommends that professional training helps to upgrade the social status of women.

Deka and Batra (2016) tried to find out the effect of Make in India on employability and the scope for skill development. It is important to focus on the development of the skills of the Indian labour force to become eligible enough to fit into the Industry requirement. As reviewed it is found only $10 \%$ of the workforce receives formal training to acquire skill requirements. But out of the actual industrial training requirement of the 22 million workforces, only 4.3 million workforces are getting formal training. It is found after reviewing various papers that there is a huge skill gap in India. Through the review of many research papers, it was found that for the successful implementation of the "Make in India" initiative, it is also important to implement various skill development initiatives to lower down the skill gap between the available skills and desired skills.

Dexter's Report (2013), a study conducted in the state of Goa which was sponsored by the Department of skill development. The main objectives of the study are to evaluate Socio-economic profile - demography, the economic profile of district by industry, state of education, to identifying developmental opportunities keeping in mind factor endowments and stakeholder perspectives, to identifying specific developmental initiatives/projects/government schemes which have an impact on employment generation, to articulating the aspirations of the youth, to identifying the current and future (2012-17 to 2017-22) skills and human resource requirements by industry and estimate the gap that exists, and to Study the existing VT infrastructure both in the private sector and the government domain. The researcher found that there is a high impact of skill development programmes on employment but it is not properly implemented in the state of Goa.

Manoj Kumar (2015) carried out the study titled, "Skilling India: An Indian Perspective in The Global Context". This paper dealt with the efforts made, recent trends, and critical issues and challenges of Skill Development in 


\section{DOI: $10.51386 / 25815946 /$ ijsms-v4i6p119}

India. According to global statistics, India has a $2 \%$ skilled workforce of the total working population. it discussed various issues like employability, economic growth and social development through skill development initiative, creating effective learners, desired practical benefit of higher education and technical education, etc. It also recommended different forms, modalities, and methods of Industry-Academia Interaction for improved results in skill development efforts for India's economy's sustainable and equitable growth and development.

Mishra (2014) study highlights the importance of human resources in resource deficient countries like India. The study uses the case study of Centurion University and Gram Tarang (CUGT). They target the marginalised section of the society and provide them inclusive education which inclines them for entrepreneurship opportunities and build capabilities of employment.

Mohd Faisal Isa (2018) conducted a study titled, “The Contribution of Skill Development in Rural Youth Development". According to the census of India in 2011, 68\% of the population resided in rural areas. The present data tells that the working population of India will surpass the working population of China by 2040 . Sixteen Ministries of the Indian government have signed over the introduction of Skill Development for effective function. Rural Development Ministry has re-organized its programme from the last experiences of 15 years in the programme of Skill Development training in the shape of the DDUGKY programme. Despite many government efforts, it is challenging to shape Skill India into Trained India.

Ms Swati Shantaram Mujumdar, March 2003, “A Study of Significance of Vocationalization of Education and Skill Development in India with special reference to the State of Maharashtra" has analyzed the present problems and possible recommendations for vocational training, skill and development sector in the state of Maharashtra. It was found that the Central government has realized the direct relation between skills-based education and its importance in gaining employment for the youth of our country. The present scenario around this sector is quite unwelcoming and there is scope for significant reforms in the area. The researcher over 2-3 years of in-depth research, identified problems in the governance, regulation, administration, planning, policy, standards and other aspects related to the Vocational Education, Training and Skill Development sector. It was found that vocational education is being provided without considering the present problems.

Narayanan (2016) This paper attempts to analyse whether the large share of informal employment is due to labour market segmentation or of competitive choice. The results of the pay gap decomposition demonstrate that informal employees earn less than formal workers not just because they are less competent, but also because their endowments provide poorer returns. As a result, policies focusing on skill development are vital but insufficient to improve formal job possibilities and close the wage gap between the formal and informal sectors.

Nyika R. (2016)5 analyzed Integrated Skills Outreach Programme as an effort by the Zimbabwean government to facilitate the participation of the youths in the mainstream of the economy. The program's goal was to help youths in developing technical and entrepreneurial skills so they could start viable businesses in local communities. Through skill development and job creation, the initiative attempted to meet the requirements of youngsters in terms of economic empowerment. This would help to solve unemployment challenges at the same time promoting productive youth engagement in the economy the study adopted a pragmatic research approach in which qualitative and quantitative research paradigms were exploited. A case study of the implementation of the ISOP programme in the Shurugwi rural community was carried out. Twenty purposively sampled ISOP graduates responded to a questionnaire. The sampling technique sought to select information-rich participants who could provide in-depth information.

Pallikadavath, Rajan, and Wilson (2016) The authors explored the relationship of post-sterilisation as well as low fertility's influence on women's skill development and formal education, and results indicate that these women prefer vocational training over skill development. Because low fertility and early sterilisation are commonly recognised as the developing reproductive norm in India, post-sterilization and -childcare women will constitute a substantial population category in terms of both number and proportion. To yet, no government policies or programmes have acknowledged this group. After sterilisation, India's new administration should examine focused skill development programmes.

Punjani (2014) researched the topic "A study on the Requirement of Skills Development for the Success of Make in India Project". The objective of the study was to analyse the requirement and existing levels of skill development in India. The data was collected from secondary sources and used a descriptive research design for this research. The study concluded that India needs urgent treatment in existing skill development policy. The 


\section{DOI: $10.51386 / 25815946 /$ ijsms-v4i6p119}

main findings of the paper were that only $10 \%$ of the Indian workforce had formal training in the form of higher education, technical education or vocational training. India has a 4.3 million annual training capacity, which is less than $20 \%$ of the industry requirement of 22 million skilled workers a year.

Shanmugham and Kishore (2012) highlight the role of IGNOU in promoting and providing impartial access to higher education and skill development in India. This work proposes Prior Learning Assessment model integration in IGNOU community college. PLA model is a well-established model as it focuses on learning by doing as compared to traditional classroom-based learning which is expected to increase skill-based human resource development. This article also proposes various working model curriculum for various levels of workers.

Tara and Kumar (2016) highlight that some specific efforts are required to enhance skill development in India, in the context of the country's transition to a knowledge-based economy, through the creation of a professional skilled workforce to enhance the skilled workforce. The study explores various government schemes and programmes related to skill development and the problems faced by them. This study also suggests some ways to counter these challenges and how government programmes can be implemented successfully.

Yadav. R. (2014) conducted a study on "Skill Development Initiatives in India: Challenges and Strategies concerning Vocational Training Initiatives in Maharashtra" which revealed that the various issues like unplanned rural-urban migration causing urban poverty, population growth, high school dropout rates, India is likely to witness a deficit of 5.25 million employable graduates and vocationally trained workforce in next few years. The main objective of the study was to increase the produce workforce in organised and unorganised sectors especially among youth, women, disabled, disadvantaged sections. In a few states, it was observed that the economic progress of the state was directly related to the development of the Technical and Vocational Education System.

The review of literature in the previous chapters reveals that more skill development centres are needed for determining the SWOT features of the beneficiaries as well as of the centre. These centres are supposed to help the beneficiaries not only for their current job but will also help in building their brighter career path ahead. It has been a matter of serious debate whether programs generated in these skill development centres have direct impact on the studying behaviour of a student or not. The research theories mentioned above suggests in both positive and hard to prove impact. So, in order to throw more light on this debate the current project is also surrounding towards the same as this debate is considered as the most important aspect for the students of these skill development centres in Haryana and hence that for the centres too. The major objective of this study is to determine the facts which show how skill development centres of Haryana can help to subsidize the performance of students of their centre.

\section{Research design}

\subsection{Research Methodology}

The major objective of this study is to determine the facts which show how skill development centres of Haryana can help to subsidize the performance of students of their centre. The current chapter discusses about the methodology adopted by the researcher to answer the objective related questions.

The above aspects are briefly described as below one by one:

\subsubsection{Aim of the Study}

This study will mainly focus on the working of skill development centres in Haryana and its impact on the beneficiaries.

\subsubsection{Validation of the Study}

The attempt of this study is to be helpful for improvising the teaching level of the development centres. The study will benefit all the skill development centres as well as the beneficiaries in order to improve their teaching and working environment. This study focuses mainly on the centres of Haryana only as the government of this state is trying its best possible way to improvise these centres on time to time basis. These centres are functioning in the rural as well as in urban areas of Haryana therefore trying to cover most of the population of Haryana state. These centres are trying to provide a helping hand to its students by providing necessary skills to 


\section{DOI: $10.51386 / 25815946 /$ ijsms-v4i6p119}

the students in almost all possible technical as well as non-technical fields. These centres also help in career development of its beneficiaries. Keeping in mind all these important aspects this has included 117 centres of Rohtak, Haryana and out of which 64 has responded to us.

\subsubsection{Sample and Data Collection}

The goal of this study is to define the technique or methods to find the data on which this research is based. The study focused both on primary and secondary sources of obtaining data for its findings. However, the main stream of data is collected mostly through the survey methods by using questionnaire and personal interaction with the respondents.

\subsubsection{Sample Size}

At the initial point of selecting centres for the study, we came across nearly 117 centres present in Rohtak through HSDM.

\subsubsection{Data Collection}

The secondary data was collected through centre's journals, prospectus, catalogues, advertisements, online sources, circulars, pamphlets, official documents etc.

The questionnaire was distributed among around 117 respondents out of which only $(61.1 \%)$ respondents filled the questionnaire. Some data is also collected via personal interaction with beneficiaries while collecting the data in the centre's premises which they were reluctant to highlight in their questionnaire.

\subsubsection{Statistical Techniques}

Frequency, Percentage, Cross tabulation, Chi square test etc. were used for the purpose of analysing the data. Chi square analysis is helpful whenever there is a requirement of testing if there are similarities between two or more variables on some characteristics of interest. It is basically used to compare if there is a relationship between the independent and dependent variables. The chi square test is used for normal data (categorical) as is the case for this study.

The relationships between the dependent and independent variables e.g. centre and skill, knowledge, ability, confidence, morale were described by conducting chi square tests based on two-way tables of counts. Chi square is very sensitive to the sample size, if the sample size is big enough, even a very small relationship becomes significant (Oluwadiya, 2010). The size of a sample affects the power of chi square. It has a high power when the size of the sample is large and low power when the size is small.

\section{Analysis and Interpretation}

Figure 1. Highlighting the mode of training, studentsare getting in the institute. 


\section{DOI: $10.51386 / 25815946 / \mathrm{ijsms}-\mathrm{v} 4 \mathrm{i} 6 \mathrm{p} 119$}

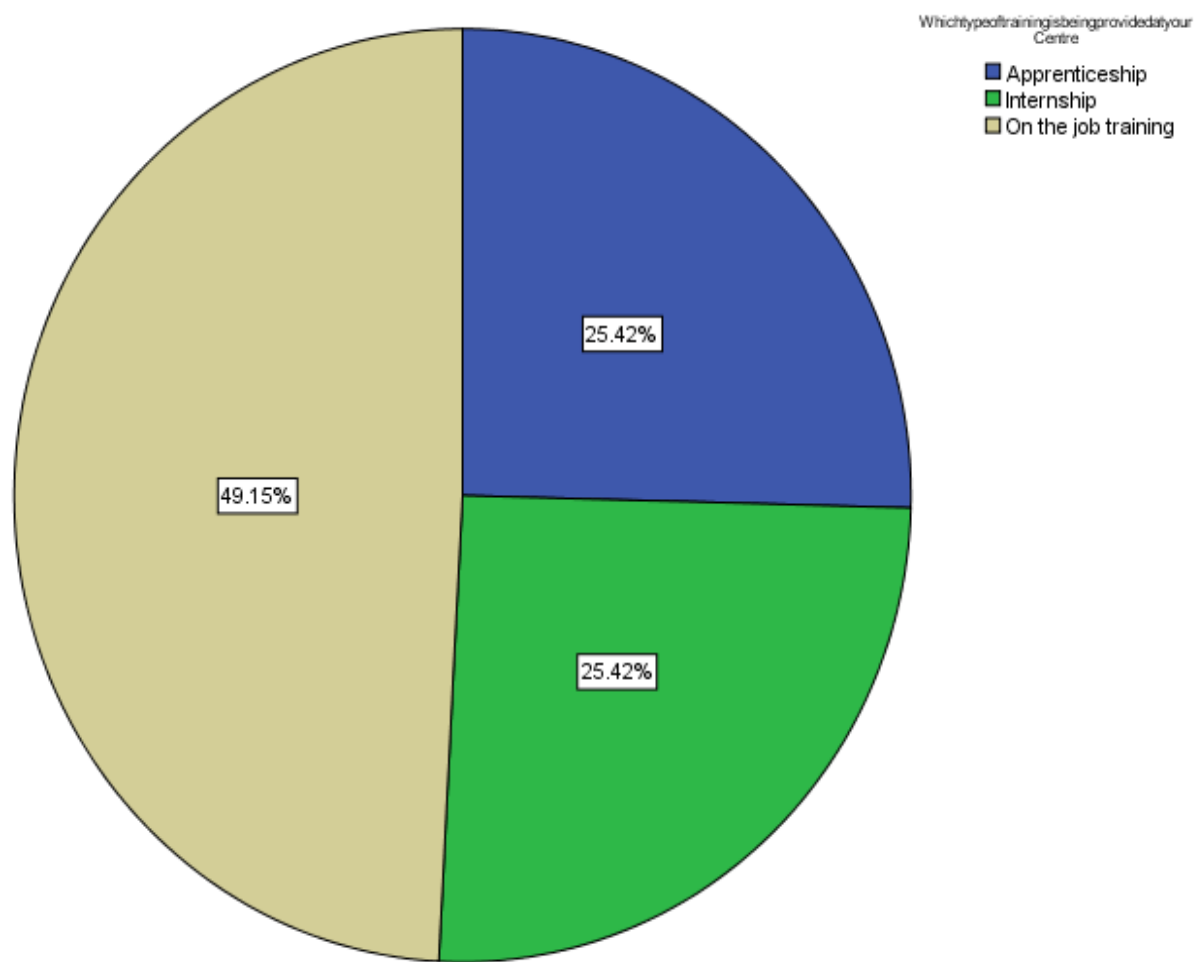

\section{Interpretation}

The above pie chart clearly indicates that on the job training is the highest (49.15\%) type of training given by the institute followed by apprenticeship and internship having equal share (25.42\% each).

Figure 2. Highlighting the Percentage of Knowledge and the Job Skills they gain in centres.

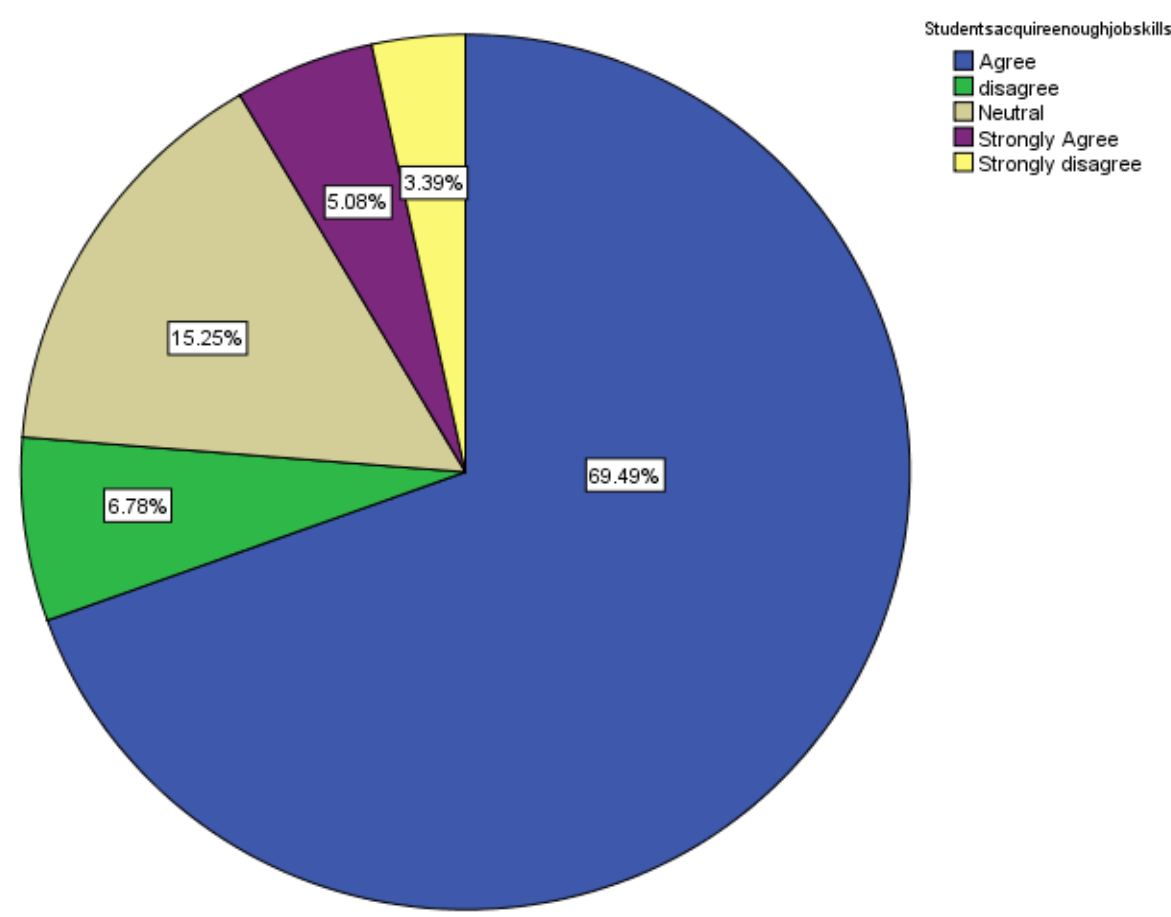




\section{DOI: $\underline{10.51386 / 25815946 / i j s m s-v 4 i 6 p 119}$}

\section{Interpretation}

The above diagram clearly states that the observed values for each category are very similar to the expected values for each category. The numbers clearly indicates that institutions are very much in acceptance of the term that students do accept enough job skills from their institute. The percentage here $69.49 \%$ shows that students are getting the enough skills from the institute. While $3.43 \%$ are strongly agree with it which totally contributes to more than $70 \%$ of agreement with the statement.

Figure 3. Representing the increase in their competency for job after joining skill centres.

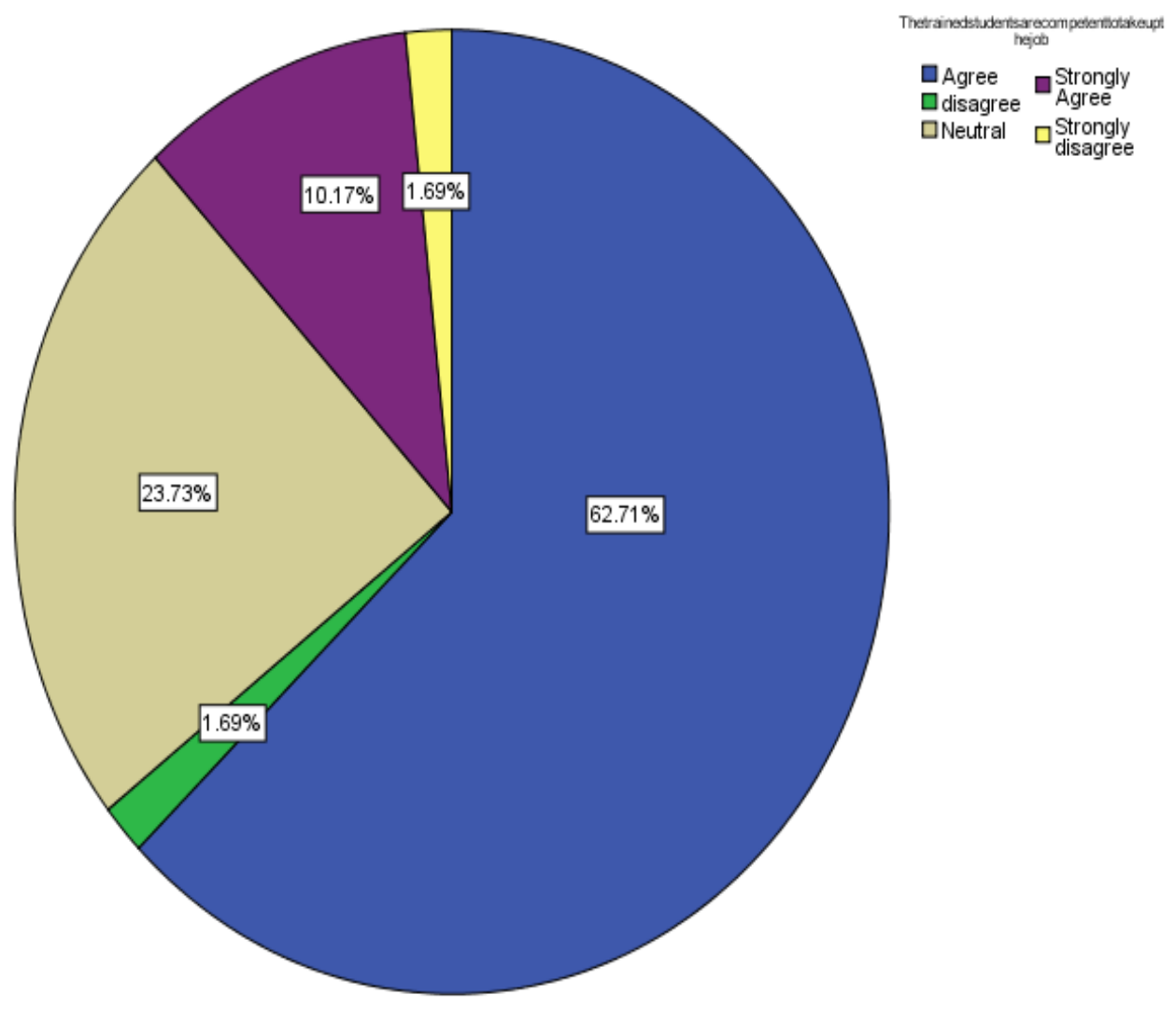

\section{Interpretation}

The pie chart extracted from the Chi Square analysis clearly indicates that the respondents are very much clear in the term that students do become competent enough to take the job after going through the training sessions. A total of $63 \%$ (62.71\% agree and $10.17 \%$ strongly agree) are agree with the question that trained students are competent enough to take up the job in their future. Only a small portion of around 3\% (1.69\% Disagree and $1.69 \%$ Strongly Disagree) of respondents do not agree with it. While $23.73 \%$ of respondents remained neutral.

Figure 4: Representing the job acquirement by trainees within a particular time period. 


\section{DOI: $10.51386 / 25815946 /$ ijsms-v4i6p119}

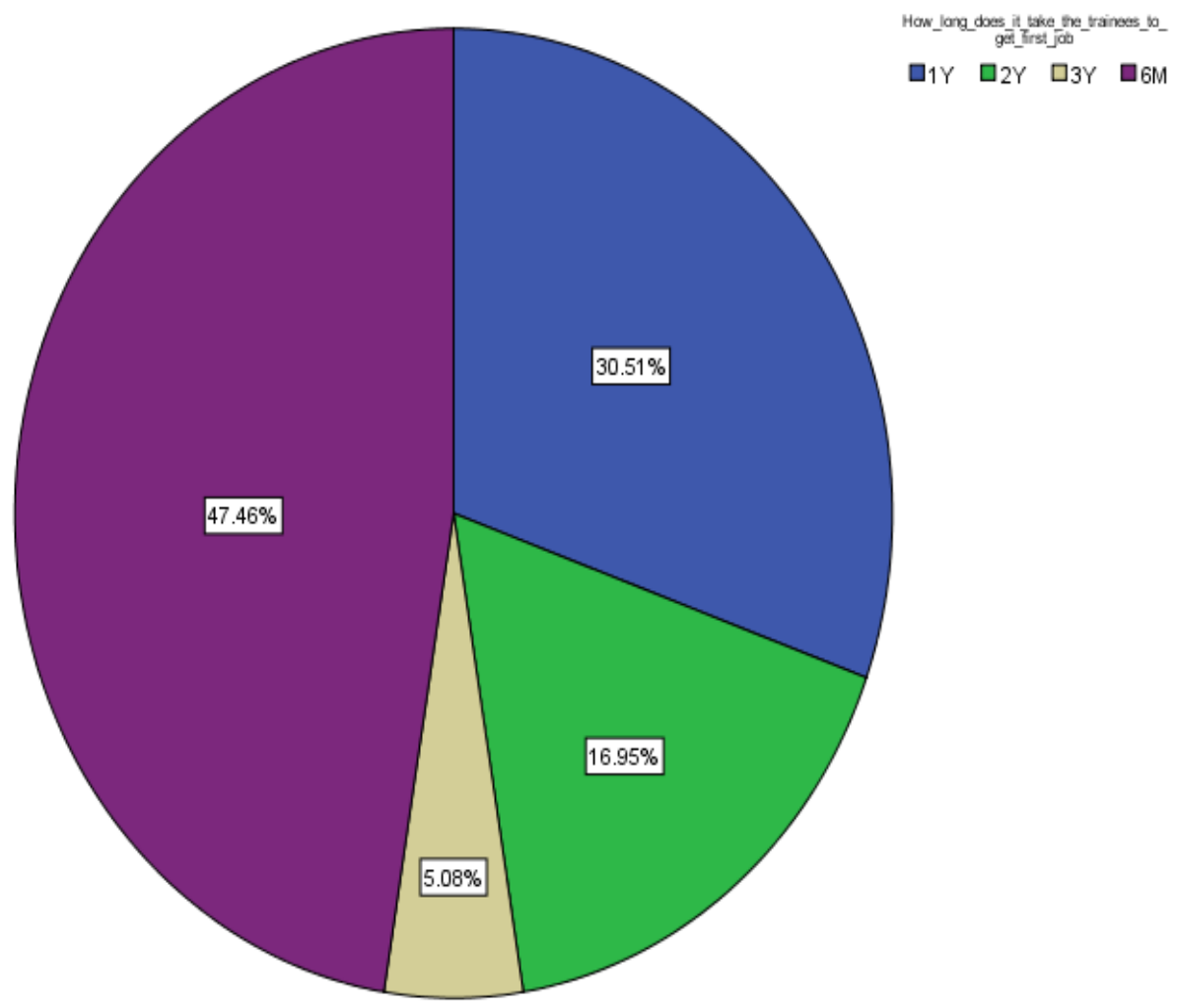

\section{Interpretation}

According to the respondents it takes almost 6 months to 1 year to take a job for a trainee of their institute. Around $78 \%$ of trainees get their job within 6 months $(47.46 \%)$ to 1 year $(30.51 \%)$. The remaining trainees also get job but after the period of 2 to 3 years $(16.95 \%$ and $5.08 \%$ respectively).

\section{Findings}

The above analysis suggests the following findings for this project:

1. The type of training provided in most of the institutes are on the job training which in further helps the trainees to gather more and more basic information about the work to be done.

2. The pie charts explain that respondents does think that around $70 \%$ students acquire enough job skills from their institute which further helps them to get job in their respective area.

3. They further added that students are in much favour of getting job after getting training from their institutes. Around $63 \%$ of respondents positively responded to it.

4. The placement percentages of most of the institutes are quite high. Around $78 \%$ of students do get their job within the time frame of 6 months to 1 year. Remaining trainees also get placed after 2 to 3 years.

5. Most of the respondents agreed to the question that skill development mission is successful in Haryana. Almost $90 \%$ of respondents replied with yes to it.

\section{Conclusions and Recommendations}

Production defining input-output relationships is a crucial aspect whose benefits can be disseminated in a variety of ways such as better wages and working conditions for employees; increase profits and profits for shareholders; environmental protection; and an increase in Government revenue. This enables businesses and the country to continue to compete in the real estate market. Product growth can be caused by a variety of factors such as new technologies, new equipment, better management practices; investment in plant and equipment and technology, improving occupational safety at the level of skills of employees; macroeconomic policies, labor market conditions, business environment and public investment in infra construction and education. 


\section{DOI: $\underline{10.51386 / 25815946 / \mathrm{ijsms}-v 4 \mathrm{i} 6 \mathrm{p} 119}$}

Therefore, it is clear that skills development is just one factor needed for product growth and should be an integral part of development policies. Policies should take into account developmental levels and the needs and requirements of the various sectors. Apart from this the skills policy should focus on improving access, quality and appropriateness of training for different categories and sectors. Evidence from developed countries shows that investment in education and skills help the economy to move to higher levels of growth and eliminate low wages, a disease of low skills development.

The major objective of this project was to identify the performance of skill development centres in Haryana. With the help of responses, we were able to achieve our objectives to some good extent.

Skill development centres are providing all the possible help to the needy and skilled students to achieve their goals and become competent enough to acquire any job of their interest.

From the above discussion it can be clearly concluded that all the skill development programs are increasing the chances of more practical knowledge of any job and are becoming a success course amongst the youth of Haryana.

An overall cooperative effort, in a coordinated manner should be encouraged in the skill development process. The need for highly skilled workforce in developing as well as developed nations has increased manifold due to globalization and competition as it enables them to accelerate the growth of the economy. All the nations of the world need skilled workforce so as to meet global standards of quality, to increase their foreign trade, to bring advanced technologies to their domestic industries and to boost their industrial and economic development. Thus, skills and knowledge becomes the major driving force of socio-economic growth and development for any country.

\section{References}

[1] Adams, A. V. (2012).The role of skills development in overcoming social disadvantage. Background paper prepared for the education for all global monitoring report.

[2] Agrawal, T. (2012). Vocational education and training in India: Challenges, status and labour market outcomes. Journal of Vocational Education and Training, 64(4), 453-474.

[3] Ahmed, T. (2016). Labour market outcome for formal vocational education and training in India: Safety net and beyond. IIMB Management Review, 28(2), 98-110.

[4] Baker, J. L. (2000). Evaluating the impact of development projects on poverty: A handbook for practitioners. World Bank Publications.

[5] Bhardwaj, B. R. (2014). Impact of education and training on performance of women entrepreneurs: A study in emerging market context. Journal of Entrepreneurship in Emerging Economies, 6(1), 38-52.

[6] Chen, D., Johnson, U. Y., Hull, D. M., \& Reid, J. K. (2016). Workplace Skills Development: A Multilevel Study of Jamaican Unattached Youth. Journal of Career Assessment, 24(2), 307-317.

[7] Das, A. K. (2015). Skills Development for SMEs: Mapping of Key Initiatives in India, Institutions and Economics, 7(2), 120-143.

[8] Deka, R. J., \& Batra, B. (2016). The Scope of Skill Development, Employability of Indian Workforce in Context of Make in India: A Study. International Journal of Engineering Technology, Management and Applied Sciences, 4(4), 275-282.

[9] Dexter's report, 2013.

[10] Gandhi, M. (2015). Skilling India: An Indian Perspective in the Global Context, Proceedings of International Academic Conferences, International Institute of Social and Economic Sciences.

[11] Groener, Z. (2013). Skill development and structural change: Possibilities for and limitations of redressing structural racial inequalities in South Africa. International Review of Education, 59(6), 723-749

[12] Grover, R.P., \& Dak, T.M. (1986). Skill Development and rural industrialization in Haryana: A Socioeconomic analysis, Indian Anthropological Association, 16(2), 139-147

[13] Hussain, T.M. (2005). Skill development, Productivity and Growth. The Pakistan Development Review, 44(4), 1153-1155.

[14] Isa, M. F. (2018). The Contribution of Skill Development in Rural Youth Development, International Education and Research Journal.

[15] Institute of Applied Manpower Research, Government of India, Planning Commission. (2011). Skill mapping in two districts: $\begin{array}{lllll}\text { Gurdaspur (Punjab) and Singrauli } & \text { (Madhya Pradesh). Retrieved from http://iamrindia.gov. } \\ \text { in/writereaddata/UploadFile/nsdc0report_1849.pdf }\end{array}$ 


\section{DOI: $\underline{10.51386 / 25815946 / \mathrm{ijsms}-\mathrm{v} 4 \mathrm{i} 6 \mathrm{p} 119}$}

Volume: 4 Issue: 6

[16] Jain, T., Maitra, P., \& Mani, Subha. (2018). Barriers to skill acquisition: Evidence from English training in India. World Development, $114,314-3$

[17] Kahlon, A.K. (2017). Skill development mission in Punjab: Key Challenges, hindrances and possible solutions. International Journal of Science, Technology and Management, 6(2), 854-857.

[18] Kanchan, S., \& Varshney, S. (2015). Skill development initiatives and strategies. Asian Journal of Management Research, 5(4), 666672 .

[19] Kishore, s. \& m. S. (2012). Integration of prior learning and assessment in the IGNOU community college system. Turkish Online Journal of Distance Education, 13(2), 311-321.

[20] Mehta, P. (2016). Skill India: Mission 2020, International Journal of Business Management and Scientific Research, 19.

[21] Mishra, M. (2014). Vertically integrated skill development and vocational training for socioeconomically marginalised youth: The experience at Gram Tarang and Centurion University, India Mukti. Springer, 44, 297-316.

[22] Moorosi, P. (2009). Gender, skill development and poverty reduction. Empowering Women for Gender Equity, 81, $110-117$.

[23] Mujumdar, M. S. S. (2012). A Study of Significance of Vocationalization of Education and Skill Development in India-with special reference to the State of Maharashtra. Unpublished Ph. D Thesis). Symbiosis International University, Pune, India. MHRD.(2014). Revised Scheme of Vocationalization of Higher Secondary Education, Department of School Education and Literacy. New Delhi: MHRD.

[24] Narayanan, A. (2015). Informal employment in India : Voluntary choice or a result of labor market segmentation? Indian Journal of Labour Economics, 58, 119-167.

[25] Nivorozhkin, A. (2005). An evaluation of government- sponsored vocational training programmes for the unemployed in urban Russia. Cambridge Journal of Economics, 29, 1053-1072.

[26] Nyika, R. (2016). Evaluation of the impact of integrated skills out-reach programme (isop) in rural communities of zimbabwe. European Journal of Research in Social Sciences, 4(3), 53-61.

[27] Okada, A. (2012). Skills Development for Youth in India: Challenges and Opportunities. Journal of International Cooperation in Education, 15(2), 169-193.

[28] Pallikadavath, S., Rajan, S. I., \& Wilson, C. (2016). Impact of low fertility and early age at sterilisation on women's formal education and skill development in South India. Journal of Population Research, 33(3), 199-220.

[29] Punjani, P. K. K. (2019). A study on the requirement of skills development for the success of "Make in India " project. Tactful Management Research Journal, 65-69.

[30] Sagar, A. (2017). A Roadmap for Skill Development in Rural India, Renewable Research Journal, 3(4), $347-355$.

[31] Saini, V. (2015). Skill Development In India: Need, Challenges And Ways. Abhinav National Monthly Refereed Journal of Research in Arts \& Education, 4(4), 10.

[32] Sanghi, M. S., Development, S., \& Aayog, N. (n.d.). Skill Development and Productivity of the Workforce. 36-51.

[33] Shanmugham, M. and Kishore, S. (2012), Integration of prior learning and assessment in the IGNOU community college system for Skill Development, Turkish Online Journal of Distance Education, 13(2), 311-321.

[34] Sharma, L., \& Nagendra, A. (2016). Skill Development in India: Challenges and Opportunities. Indian Journal of Science and Technology, 9(48), 1-12.

[35] Tara, S. N., \& Kumar, N. S. S. (2016). Skill development in India : In conversation with S . Ramadorai , Chairman , National Skill Development Agency \& National Skill Development Corporation; former CEO, MD and Vice Chairman , Tata Consultancy Services. IIMB Management Review, 28(4), 235-243.

[36] Venkateshwarlu, N., Sharma, R., \& Agarwal, A. (2016). Skill development training Programme: A Case study of IGNOU. Global Journal of Enterprise Information system, 8(4), 66-70.

[37] Vyas, A. (2018). The Impact of Skill Development on Women Empowerment. International Journal of Advance Research and Development, 3(1), 8-11.

[38] Yadav, M. R. (2014). Skill Development Initiatives in India: Challenges and Strategies with Reference to Vocational Training Initiatives in Maharashtra. Tactful Management Research Journal, 2319-7943.

[39] www.hsdm.org.in 